\title{
STUDENT PERCEPTIONS OF ESP COURSE FOR CYNOLOGICAL TRANSLATORS
}

\author{
Iryna Liashenko \\ Sumy State University, Ukraine \\ E-Mail: i.liashenko@uabs.sumdu.edu.ua
}

\begin{abstract}
The modern requirements to the educating professionals in every sphere arise in every specialism, even in the new and developing. The actual demand in training the cynological translators assistants of show judges is becoming increasingly actual. Thus, this study is centered on student perceptions of ESP course for cynological translators to increase course efficiency and student learning, which is thought to be the first research in this area. Using students survey data from the two first batches of the ESP course on preparing these professionals, this article explores the linkage between the structural components of the course and the improved students' achievement, using the confirmatory factor analysis. We also examined possible suggestions for improving the design of the course. The results provided support for our theory of action about using a system structural design with practical traineeship, which results in improved student achievements. The results proved the total value of the course with the increasing absolute achievement of students and qualitative achievement and the rank correlation method.
\end{abstract}

Key words: ESP course, student perceptions, Cynology, cynological translators

\section{INTRODUCTION}

The ongoing changes in the variety of jobs create new specialisms in preparing the professionals in different spheres. One of the recent demands which have faced the professionals in Cynology in Ukraine is lack of interpreters in the rings who assist the foreign judges while describing the dogs at the conformation shows. Today, there is broad mobility of representatives of the canine sphere all over the world, which requires the necessity to acquire the information related to the subject. The canine world is developing in a multidimensional way: Kennel Clubs tend to invite foreign show judges for working in the show rings for the most objective evaluation of the national and international livestock. Professional breeders and dog-handlers, as well as the dog owners and enthusiasts and professionals in the sphere of care, training, grooming, zoopsychology and other, are communicating on many issues, which are specific to the canine world. This interrelation requires specific cynological language, mostly English. Those professionals, who have general English skills, seem to have difficulties with translation and are not always able to find an exact meaning of the terms and specific description of the animals. Moreover, giving critiques to the animals in the rings, the show judges may use the special jargon, which is designed for properly defining the benefits and drawbacks of the livestock bred nowadays. Today, there are a lot of professionals being prepared with 
different specialisms in the English language. Those professionals who have general English skills seem to come across challenges with the translation and are not always able to find an exact meaning of the terms and specific description of the animals. Although there is a great number of well-designed courses on Business, Marketing, Law, IT, Engineering, Agriculture and a lot of other spheres, we were not able to find any studies on the specialised courses on Cynology in English. To cover the lack of professionals in this field, we designed a vocabulary distance course on training the translators in Cynology bearing in mind the requirements for designing a course in ESP.

Our theory of action draws on the principles of designing an ESP course which is discussed by a number of researchers (Hutchinson and Waters 1984; Lowe 2009; Huhta et al. 2013; Kaur 2007; Coffey 1984; Pranckevičiūtè and Zajankauskaite 2012; Anthony 1997) that suggests that a correctly defined training gap and principles in the course designing will have positive impacts on the performance in practice. These findings are consistent with other research on the course designing that highlights the importance of considering the parameters in ESP course. In particular, we found useful the ideas that there are three main syllabuses in course designing syllabuses: a content syllabus, a language syllabus, and a learning/skills syllabus (Lowe 2009). While creating a course, we followed the principles: our course is intensive, the learners' performance is assessed, the course deals both with immediate and delayed needs, the teacher is both a provider of knowledge and facilitator (Dudley-Evans et al. 1998). The course has a rather narrow specific focus in describing the dogs from the point of morphology, types, and details. Our course runs parallel with the traineeship in the rings as the stewards in the show ring teams. The groups are heterogeneous. The professional content of the course is worked out by the experts in this field who are practicing cynologists and have constant practice in this field. The language training instrumental scaffold has been built by a professional language teacher taking into account the methodological issues in designing course for ESP students (Dudley-Evans et al. 1998).

This study attempts to describe the creation of the course and to identify the lacks in ESP course designing and ties the course with the practical usage in professional activity.

Against this background, the purpose of this study is to answer the research question: "How can we improve the ESP course for cynological translators for working in the rings?" More specifically, the research questions driving this study are as follows:

1. Is the course successful?

2. What are further improvements for this course?

To investigate these questions, we used confirmatory factor analysis to identify the main latent factors of efficient components in ESP course designing. This analysis provides evidence for the validity of the scales developed to assess the validity of the course and confirms that the developed design of the course postulated in the theory of action linking theory to practice are in place.

We first discuss a theory of action for designing a good ESP course for translators in Cynology, followed by a discussion of the relevant literature about main principles and components of the ESP course. Furthermore, we present the data and our methodology. Having analysed the results, we conclude with a discussion of the results and the implications for future research. 


\section{DESIGNING A GOOD ESP COURSE THEORY OF ACTION}

For creating an efficient course in ESP, an ESP course needs to be treated as a coherent system. The researchers argue that the ESP course has absolute and variable characteristics, such as meeting specific needs of the learner, relation in content to authentic activities, appropriateness to vocabulary, speaking, reading, writing in this sphere and others, and that these elements are efficient tools for creating an ESP course (Dudley-Evans et al. 1998; Strevens 1988; Basturkmen 2010). We argue that in addition to these elements, a good ESP course should have profound stress on authentic practice and close collaboration with the experts and practitioners in this field. Figure 1 illustrates our potential theory of action that links effectively designed ESP course to improved outcome in student learning.

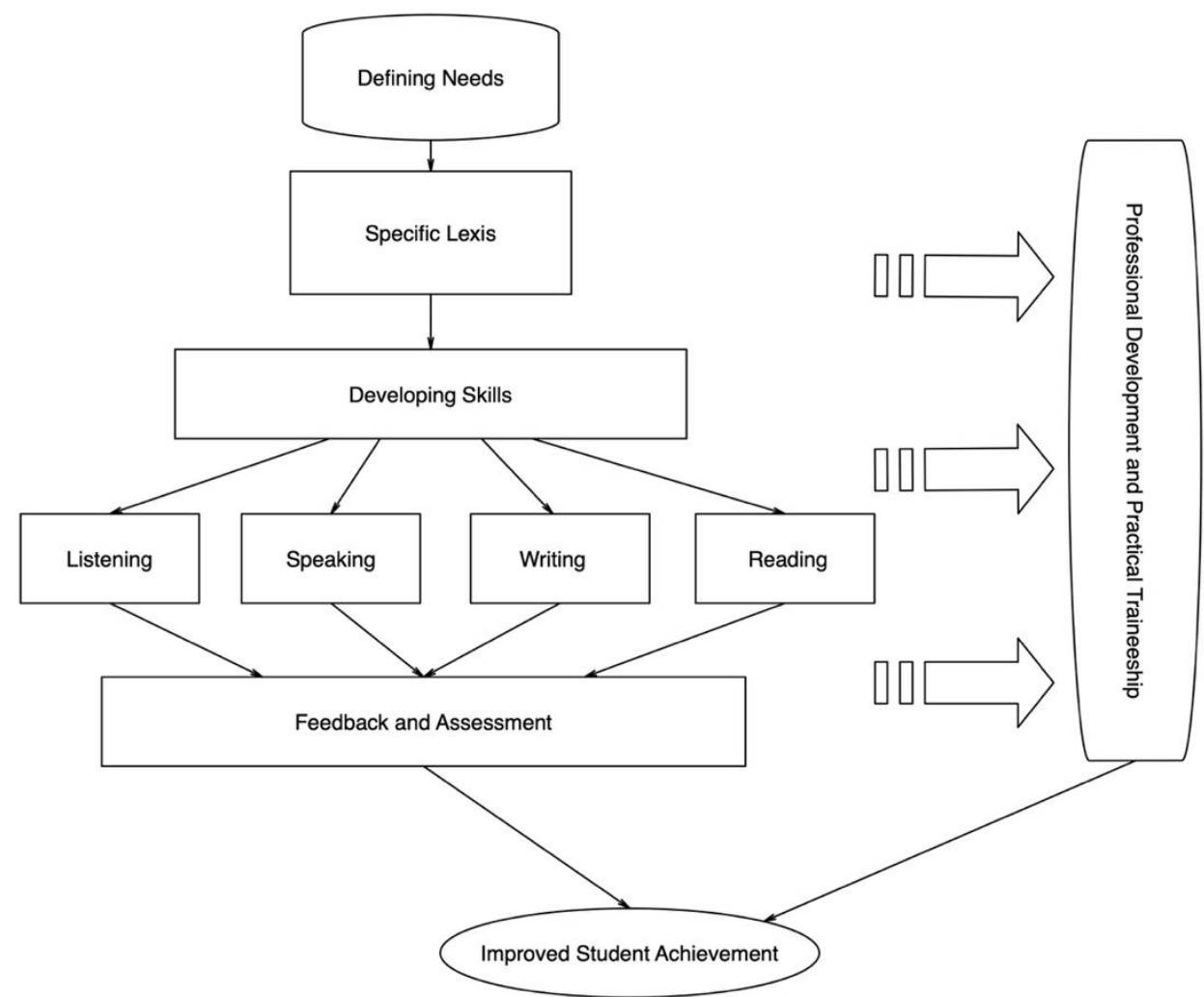

Fig. 1 ESP Course for Cynological Translators Theory of Action

\section{RELEVANT LITERATURE}

Accepting the importance of correct designing of an ESP course and the linkages in its structure, many studies pertain to evaluating and creating the programmes or courses in the specific training (Klimova 2015; Salazar 2017; Cerón 1997; Khan et al. n.d; Stefanescu 2013; Frydenberg 1982). Several studies argue on an ESP course design, presenting the structural ideas on its components (Damião 2011; Sanz and Sáez 2016; 
Nurpahmi 2017). Defining a gap or needs analysis is a cornerstone in course design, therefore this issue draws careful attention to the studies on the ESP field. Needs analysis reveals the types of needs, lacks and wants, which are subsequently categorised into personal, learning and professional needs (Hutchinson and Waters 1987). Types of needs in ESP are determined in many other ways: felt needs and perceived needs (Berwick 1989), subjective and objective needs (Brindley 1989), psychological and cognitive needs, sociological needs and methodological needs (Alavi 2014). Three different levels in categorizing needs are suggested: the micro-, meso- and macro-levels of need, where micro-level needs are the needs of the individual learner, meso-level needs are the needs in the context of the workplace or education institution and macro-level needs are the needs of society (Robinson 1991). Several studies agree on the importance of starting the design of an ESP course with the identifying the needs or training gap (Petrova 2008; Lin et al. 2014; Todea and Demarcsek 2017).

The main aim of the course is to enable the students to function effectively in a professional situation. This highlights the importance of close cooperation with experts and authentic materials. Thus, the material selection should be aimed to enable students to function successfully in authentic situations. Some researchers state that ESP practitioners must collaborate closely with the field specialists (Anthony 2007; Chamberlain and Baumgardner 1988; Nurpahmi 2017; Javid 2015). The studies have stressed that the role of an ESP practitioner should be extremely professional in the related field. We find that the authenticity of training is inseparable from the ESP courses design.

Work requirements or demand for training is considered to be one of the important constituents in ESP training (Huckin 1988; Salazar 2017). These make the professional needs in gaining professional development.

One of the most important parts of the ESP course is lexis. Acquiring specific vocabulary is directly related to the professional target. The materials of the course should reflect the needs and bridge the authentic environment at a working place (Bracaj 2014). We find that the real professional training shapes the derived theoretical knowledge into the practically correct skills.

The necessity of selecting the lexical sources graded by difficulty levels is outlined by the researchers (Schleppegrel and Bowman 1986). These findings are consistent with other research lexical levels which highlight the necessity of lexical relevance of the course (Farrel 2002). There is also a suggestion that the teachers should thoroughly choose the necessary type of vocabulary for the students according to their needs (Brooks 2014).

Several studies research the approaches in vocabulary teaching in the ESP context (Xhaferi 2015; Kavaliauskienë 2001), particularly the idea that the most efficient approach in ESP is a lexical one is claimed (Kavaliauskienë and Janulevièienë 2001). The teacher of ESP should be aware of the core technical vocabulary and an authentic functional language (Schleppegrell 1985). The study of an expert demonstrates four types of vocabulary for teaching in ESP context, such as spoken and written vocabulary, core and non-core vocabulary, discourse structural vocabulary and procedural vocabulary, technical, semitechnical and general vocabulary (Wu and Binbin 2004). Similarly, the theoretical and practical aspects of lexicographic codification of English-based terms are outlined and the importance of specific vocabulary for efficient and high-quality work is stated (Milic 2015). The importance of authenticity of vocabulary is also highlighted in the studies of the researchers (Adrianova and Makarova 2016). 
The main source of vocabulary items is lexical sets, particularly the subject-specific words from authentic reading and listening texts, which the design of the course should rely on. Reading and listening lessons are intended to challenge the learners in ESP. Popular sources in our case are the real critiques of the dogs, taken from show judges reports and audio scripts made in the show rings. The skills of reading and listening are extremely important for the interpreters in the dog conformation shows. They need to react fast, be very precise in giving the detailed description, pay attention to the grades in describing the animals.

As for writing skills, they are of lesser importance for this particular activity. Due to the specific requirements, the interpreters may be able to make notes of the evaluation of a dog, which mostly has specific short structure and construction, therefore the skills of writing fast and correctly are valuable in these situations.

Grammar has a very low prominence in this course. It appears only to support the communicative aims of the course in the semi-technical or even general situations.

The importance of implementing process assessment in ESP courses is outlined in the studies of (Giménez 1996; Douglas 2001). Assessment in ESP courses should specify both authenticity and purpose, i.e. how closely the test tasks relate to tasks in the domain (Knoch and Macqueen 2016). A specific purpose language test is defined like the one in which test content and methods are derived from an analysis of the characteristics of a specific target language and is authentically representative of the target situation defines (Douglas 2001). Therefore, assessment has to focus on role-plays of authentic situations and real-life tasks. Success is measured in terms of effective communication and the ability to get the aim.

\section{DATA AND METHODS}

In this analysis, we use the data from a survey of future translators - assistants of show judges of their perception of the designed course. The course was made according to the main professional needs based on acquiring the knowledge of the specific language and skills, necessary in the work in the show ring. The course included the questions about relevance to Cynology, expectations and received results about the course. Then the students who completed the course were asked to assess the structural components of the course according to their practical value. Also, the students gave their feedback about the most valuable and useful things in the course for their needs, which was helpful for the further improvement of the course.

Data on students' perceptions of the course for cynological translators and its impacts were collected as part of an evaluation of the implementation using an internet-based survey. The survey was administered in autumn 2018 of full implementation and counted 17 respondents from the first batch of students enrolled in 2017 and the second one in 2018.

This analysis focused on a set of 20 survey items (Table 1) that were designed to measure students' perception of the value of the distance course for cynological translators and were ranged. 
Table 1 Initial table interpreted in the numerical form

\begin{tabular}{|c|c|c|c|c|c|c|}
\hline \multirow[t]{2}{*}{ Expert } & $\begin{array}{l}\text { Level of student } \\
\text { contribution to } \\
\text { the study } \\
\text { process }\end{array}$ & $\begin{array}{l}\text { Level of } \\
\text { expectations of } \\
\text { the course }\end{array}$ & $\begin{array}{l}\text { Level of initial } \\
\text { knowledge }\end{array}$ & $\begin{array}{l}\text { Level of } \\
\text { knowledge after } \\
\text { the course }\end{array}$ & $\begin{array}{l}\text { The total value } \\
\text { of the course }\end{array}$ & $\begin{array}{l}\text { The practical } \\
\text { value of the } \\
\text { course }\end{array}$ \\
\hline & 1 & 2 & 3 & 4 & 5 & 6 \\
\hline 1 & 5 & 5 & 4 & 5 & 5 & 5 \\
\hline 2 & 4 & 5 & 3 & 4 & 5 & 5 \\
\hline 3 & 4 & 5 & 2 & 4 & 5 & 5 \\
\hline 4 & 4 & 4 & 4 & 4 & 4 & 4 \\
\hline 5 & 4 & 5 & 2 & 4 & 5 & 4 \\
\hline 6 & 2 & 4 & 3 & 4 & 4 & 4 \\
\hline 7 & 4 & 5 & 3 & 5 & 5 & 5 \\
\hline 8 & 5 & 5 & 3 & 5 & 5 & 5 \\
\hline 9 & 3 & 4 & 4 & 5 & 5 & 5 \\
\hline 10 & 3 & 4 & 4 & 5 & 5 & 4 \\
\hline 11 & 4 & 5 & 3 & 4 & 5 & 5 \\
\hline 12 & 4 & 5 & 3 & 5 & 5 & 5 \\
\hline 13 & 5 & 5 & 4 & 5 & 5 & 5 \\
\hline 14 & 3 & 4 & 4 & 5 & 5 & 4 \\
\hline 15 & 4 & 5 & 3 & 5 & 5 & 5 \\
\hline 16 & 3 & 1 & 3 & 3 & 1 & 2 \\
\hline \multirow[t]{2}{*}{17} & 4 & 4 & 2 & 4 & 4 & 5 \\
\hline & $\begin{array}{c}1 \text { - poorly } \\
5 \text { - very diligent }\end{array}$ & $\begin{array}{l}1 \text { - definitely not } \\
5 \text { - definitely so }\end{array}$ & $\begin{array}{l}1 \text { - very low } \\
5 \text { - excellent }\end{array}$ & $\begin{array}{l}1 \text { - very low } \\
5 \text { - excellent }\end{array}$ & $\begin{array}{c}\text { Target Change } \\
1 \text { - very low } \\
5 \text { - excellent }\end{array}$ & $\begin{array}{c}1-\text { not useful at } \\
\text { all } \\
5 \text { - very useful }\end{array}$ \\
\hline
\end{tabular}

Table 1 (Cont'd) Initial table interpreted in the numerical form

\begin{tabular}{|c|c|c|c|c|c|}
\hline Expert & $\begin{array}{l}\text { Level of student } \\
\text { load during the } \\
\text { course }\end{array}$ & $\begin{array}{l}\text { The level of } \\
\text { materials } \\
\text { publicity }\end{array}$ & $\begin{array}{c}\text { The level of } \\
\text { sufficiency of } \\
\text { materials on the topic } \\
\text { "General Description } \\
\text { of the Dog" }\end{array}$ & $\begin{array}{l}\text { The level of } \\
\text { sufficiency of } \\
\text { materials on the } \\
\text { topic "Head } \\
\text { Description" }\end{array}$ & $\begin{array}{c}\text { The level of } \\
\text { sufficiency of } \\
\text { materials on the topic } \\
\text { "Tooth System } \\
\text { Description" }\end{array}$ \\
\hline & 7 & 8 & 9 & 10 & 11 \\
\hline 1 & 5 & 5 & 3 & 3 & 3 \\
\hline 2 & 5 & 4 & 3 & 3 & 3 \\
\hline 3 & 5 & 5 & 2 & 2 & 2 \\
\hline 4 & 5 & 4 & 2 & 2 & 3 \\
\hline 5 & 5 & 5 & 2 & 3 & 3 \\
\hline 6 & 4 & 4 & 2 & 2 & 2 \\
\hline 7 & 4 & 5 & 3 & 3 & 3 \\
\hline 8 & 5 & 5 & 3 & 3 & 3 \\
\hline 9 & 4 & 4 & 2 & 3 & 3 \\
\hline 10 & 3 & 3 & 3 & 3 & 3 \\
\hline 11 & 4 & 4 & 3 & 3 & 3 \\
\hline 12 & 5 & 5 & 3 & 3 & 3 \\
\hline 13 & 5 & 5 & 2 & 2 & 2 \\
\hline 14 & 4 & 4 & 3 & 3 & 3 \\
\hline 15 & 4 & 4 & 3 & 3 & 3 \\
\hline 16 & 4 & 4 & 3 & 3 & 3 \\
\hline \multirow[t]{2}{*}{17} & 5 & 5 & 3 & 3 & 3 \\
\hline & $\begin{array}{l}1 \text { - definitely not } \\
5 \text { - definitely so }\end{array}$ & $\begin{array}{c}1 \text { - definitely not } \\
5 \text { - definitely so }\end{array}$ & $\begin{array}{l}3 \text { - the content was } \\
\text { sufficient } \\
2 \text { - nearly sufficient } \\
1 \text { - insufficient content }\end{array}$ & $\begin{array}{l}3 \text { - the content was } \\
\text { sufficient } \\
2 \text { - nearly sufficient } \\
1 \text { - insufficient } \\
\text { content }\end{array}$ & $\begin{array}{l}3 \text { - the content was } \\
\text { sufficient } \\
2 \text { - nearly sufficient } \\
1 \text { - insufficient } \\
\text { content }\end{array}$ \\
\hline
\end{tabular}


Table 1 (Cont'd) Initial table interpreted in the numerical form

\begin{tabular}{|c|c|c|c|c|}
\hline Expert & $\begin{array}{l}\text { The level of sufficiency } \\
\text { of materials on the topic } \\
\text { "Neck and Body } \\
\text { Description" }\end{array}$ & $\begin{array}{l}\text { The level of sufficiency } \\
\text { of materials on the topic } \\
\text { "Limbs Description" }\end{array}$ & $\begin{array}{c}\text { The level of sufficiency } \\
\text { of materials on the topic } \\
\text { "Movements } \\
\text { Description" }\end{array}$ & $\begin{array}{l}\text { The level of sufficiency } \\
\text { of materials on the topic } \\
\text { "Colour Description" }\end{array}$ \\
\hline & 12 & 13 & 14 & 15 \\
\hline 1 & 3 & 3 & 3 & 3 \\
\hline 2 & 3 & 3 & 3 & 3 \\
\hline 3 & 2 & 2 & 2 & 2 \\
\hline 4 & 3 & 3 & 3 & 2 \\
\hline 5 & 3 & 3 & 3 & 2 \\
\hline 6 & 2 & 2 & 2 & 2 \\
\hline 7 & 3 & 3 & 3 & 3 \\
\hline 8 & 3 & 3 & 2 & 2 \\
\hline 9 & 3 & 3 & 2 & 3 \\
\hline 10 & 1 & 3 & 3 & 3 \\
\hline 11 & 3 & 3 & 3 & 3 \\
\hline 12 & 3 & 3 & 3 & 3 \\
\hline 13 & 2 & 2 & 2 & 2 \\
\hline 14 & 3 & 3 & 3 & 3 \\
\hline 15 & 3 & 3 & 3 & 3 \\
\hline 16 & 3 & 3 & 3 & 3 \\
\hline \multirow[t]{2}{*}{17} & 3 & 3 & 3 & 3 \\
\hline & $\begin{array}{c}3 \text { - the content was } \\
\text { sufficient } \\
2 \text { - nearly sufficient } \\
1 \text { - insufficient content }\end{array}$ & $\begin{array}{c}3 \text { - the content was } \\
\text { sufficient } \\
2 \text { - nearly sufficient } \\
1 \text { - insufficient content }\end{array}$ & $\begin{array}{c}3 \text { - the content was } \\
\text { sufficient } \\
2 \text { - nearly sufficient } \\
1 \text { - insufficient content }\end{array}$ & $\begin{array}{c}3 \text { - the content was } \\
\text { sufficient } \\
2 \text { - nearly sufficient } \\
1 \text { - insufficient content }\end{array}$ \\
\hline
\end{tabular}

Table 1 (Cont'd) Initial table interpreted in the numerical form

\begin{tabular}{|c|c|c|c|c|c|}
\hline Expert & $\begin{array}{c}\text { The importance of } \\
\text { developing more: } \\
\text { vocabulary }\end{array}$ & $\begin{array}{c}\text { The importance of } \\
\text { developing more: } \\
\text { listening }\end{array}$ & $\begin{array}{l}\text { The importance of } \\
\text { developing more: } \\
\text { writing }\end{array}$ & $\begin{array}{c}\text { The importance of } \\
\text { developing more: } \\
\text { reading }\end{array}$ & $\begin{array}{c}\text { The importance of } \\
\text { developing more: } \\
\text { speaking }\end{array}$ \\
\hline & 16 & 17 & 18 & 19 & 20 \\
\hline 1 & 1 & 2 & 1 & 2 & 1 \\
\hline 2 & 1 & 1 & 2 & 2 & 1 \\
\hline 3 & 3 & 3 & 3 & 3 & 3 \\
\hline 4 & 2 & 1 & 4 & 4 & 4 \\
\hline 5 & 1 & 1 & 2 & 3 & 2 \\
\hline 6 & 2 & 1 & 2 & 2 & 1 \\
\hline 7 & 2 & 2 & 4 & 3 & 3 \\
\hline 8 & 1 & 1 & 1 & 1 & 1 \\
\hline 9 & 4 & 2 & 2 & 2 & 2 \\
\hline 10 & 4 & 4 & 3 & 4 & 4 \\
\hline 11 & 2 & 2 & 3 & 3 & 3 \\
\hline 12 & 1 & 1 & 4 & 3 & 2 \\
\hline 13 & 2 & 2 & 2 & 2 & 2 \\
\hline 14 & 2 & 2 & 2 & 2 & 2 \\
\hline 15 & 2 & 2 & 2 & 2 & 2 \\
\hline 16 & 4 & 4 & 3 & 4 & 4 \\
\hline \multirow[t]{2}{*}{17} & 2 & 1 & 1 & 4 & 1 \\
\hline & $\begin{array}{l}1 \text { - definitely so } \\
5 \text { - definitely not }\end{array}$ & $\begin{array}{l}1 \text { - definitely so } \\
5 \text { - definitely not }\end{array}$ & $\begin{array}{l}1 \text { - definitely so } \\
5 \text { - definitely not }\end{array}$ & $\begin{array}{l}1 \text { - definitely so } \\
5 \text { - definitely not }\end{array}$ & $\begin{array}{l}1 \text { - definitely so } \\
5 \text { - definitely not }\end{array}$ \\
\hline
\end{tabular}




\section{RESULTS}

This model identified 20 factors with all indicators significantly loading onto the factors according to the Likert scale statements. The first eight items and the last five were labelled ranging from 1 to 5 , where item 1 ("Level of student contribution to study process") has the scale points ranked from 1 as "Poorly" to 5 as "Very diligent"; items 35 ranked from 1 ("Very Low") to 5 ("Excellent"); item 6 (Practical value of the course) was labelled from 1 ("Not useful at all") to 5 ("Very useful"); items 2, 7, 8, 16-20 were numbered ranging from 1 ("Definitely So") to 5 ("Definitely Not"). Items 9-15, which represented students' perception of the structural components of the course were labelled ranging from 1 ("Insufficient Content") to 3 ("The Content Was Sufficient"). This table is a matrix of points (Table 1).

In order to conduct a further analysis of this survey, we needed to convert it into the matrix of rank by applying a rank correlation method (Table 2, Appendix A). To do this, the data obtained in the points was reordered as we reduced and assigned a serial number that determined the location of each factor in the aggregate, that is, to assign a rank.

If an expert assigns the same number of points to several factors, they are assigned a standardized rank, that is, the proportion of the division of the sum of places occupied by factors of equal rank into the total number of such alternatives.

On the basis of the matrix of ranks, we constructed a matrix of advantages, the essence of which was to estimate how many experts preferred this factor in comparison with others, or the number of cases where the factor $j$ was defined as more important in the $\mathrm{z}$ direction (Table 3, Appendix A).

To determine the element $a b$ (cell at the intersection of the line and column $b$ ) matrix benefits analyzed the lines $a$ and $b$ matrix ranks and were determined by how many times ranks factor and higher compared with the ranks factor $b$, or how many times the line item and the smaller items line $b$.

To assess the importance of factors, it was necessary to calculate a number of indicators:

1) Sum of ranks assigned to the $\mathrm{j}$ factor:

$$
S_{j}=\sum_{i=1}^{m} R_{i j}
$$

where: $\mathrm{Sj}$ - the sum of ranks assigned to the $\mathrm{j}$ factor;

$\mathrm{m}$ - the number of experts who participated in the study;

$\mathrm{n}$ - the number of factors of research;

Rij is the rank of an $\mathrm{i}$-th expert of the $\mathrm{j}$-th factor .

2) Average rank for each factor:

$$
\bar{S}_{j}=\frac{\sum_{i=1}^{m} R_{i j}}{m}=\frac{S_{j}}{m}
$$

3) The average value in points:

$$
M_{j}=\frac{\sum_{i=1}^{m} c_{i j}}{m_{j}}
$$

where: with $\mathrm{ij}$ - an estimate of the relative weight (in balls), the data and-th expert of the $\mathrm{j}$ factor;

$\mathrm{mj}$ - the number of experts who participated in the $\mathrm{j}$-th factor study. 
4) The average weight of each factor (normalized score):

$$
W_{j}=\frac{\sum_{i=1}^{m} w_{i j}}{\sum_{j=1}^{n} \sum_{i=1}^{m} w_{i j}}
$$

where:

$$
w_{i j}=\frac{c_{i j}}{\sum_{j=1}^{n} c_{i j}}
$$

The results of the calculations are given in the table (Table 4).

Table 4 Importance of factors

\begin{tabular}{|c|c|c|c|c|}
\hline Factors & $\mathrm{S}_{\mathrm{j}}$ & $\mathrm{S}_{\mathrm{i}}$ average & $\mathrm{M}_{\mathrm{j}}$ & $\mathrm{W}_{\mathrm{j}}$ \\
\hline 1 & 131,50 & 7,74 & 3,82 & 0,0593 \\
\hline 2 & 83,50 & 4,91 & 4,41 & 0,0686 \\
\hline 3 & 180,50 & 10,62 & 3,18 & 0,0494 \\
\hline 4 & 78,00 & 4,59 & 4,47 & 0,0695 \\
\hline 5 & 71,50 & 4,21 & 4,59 & 0,0713 \\
\hline 6 & 77,50 & 4,56 & 4,53 & 0,0704 \\
\hline 7 & 77,50 & 4,56 & 4,47 & 0,0699 \\
\hline 8 & 82,50 & 4,85 & 4,41 & 0,0689 \\
\hline 9 & 230,00 & 13,53 & 2,65 & 0,0411 \\
\hline 10 & 218,50 & 12,85 & 2,76 & 0,0430 \\
\hline 11 & 214,50 & 12,62 & 2,82 & 0,0438 \\
\hline 12 & 220,00 & 12,94 & 2,71 & 0,0421 \\
\hline 13 & 214,50 & 12,62 & 2,82 & 0,0438 \\
\hline 14 & 224,50 & 13,21 & 2,71 & 0,0420 \\
\hline 15 & 228,00 & 13,41 & 2,65 & 0,0411 \\
\hline 16 & 257,00 & 15,12 & 2,12 & 0,0330 \\
\hline 17 & 277,50 & 16,32 & 1,88 & 0,0291 \\
\hline 18 & 240,00 & 14,12 & 2,41 & 0,0372 \\
\hline 19 & 214,00 & 12,59 & 2,71 & 0,0420 \\
\hline 20 & 249,00 & 14,65 & 2,24 & 0,0344 \\
\hline
\end{tabular}

The assessment of the relative importance of the factors contained in the table indicates that the most important issues for the group of experts are the issues covered by the factors 4-8 and less inclined to consider the useful factors assessed in questions 16 and 17.

The average weight of each factor indicates that the most important and promising are factors $4-8$, which is confirmed by the high values of this indicator and in relation to the values for other factors.

Factors 4-8 "Level of knowledge after the course", "Total value of the course", "Practical value of the course", "Level of student load during the course" and "The level of materials publicity" state the students' perception of the meaningfulness of the course in their activities. Moreover, the answers to the question about the necessity of the course show the prevalence of the professional importance of the course for them. 
The survey contained qualitative question "What was the most precious and useful in the course for you?". The answers mostly related to the professional lexis, which was one of the most important factors for the translators to work in the dog show ring ("terminology, special approach and correctly formed tests", "dictionary and literature", "audio recordings with real descriptions", "professional vocabulary, plausible realistic dog profiles", "true descriptions of dogs", "variety of descriptions", "the words", "lexis", etc).

To assess the generalized degree of consistency of opinion on all factors we calculated a number of indicators:

1) Concordance coefficient:

$$
K_{\text {кон }}=\frac{\sum_{j=1}^{n} d_{j}^{2}}{\frac{1}{12}\left[m^{2}\left(n^{3}-n\right)-m \sum_{i=1}^{m} T_{i}\right]}
$$

де:

$$
\begin{gathered}
d_{j}=S_{j}-\frac{\sum_{j=1}^{n} S_{j}}{n} \\
S_{j}=\sum_{i=1}^{m} R_{i j} \\
T_{i}=\sum_{l=1}^{L}\left(t_{l}^{3}-t_{l}\right)
\end{gathered}
$$

$\mathrm{L}$ - the number of groups of related (identical) rank; $t_{1}$ - the number of bound ranks in each group.

2) Pearson Fitting Criterion:

$$
\chi_{p}^{2}=\frac{\sum_{j=1}^{n} d^{2}}{\frac{1}{12}\left[m n \times(n+1)-\frac{1}{n-1} \sum_{i=1}^{m} T_{i}\right]}
$$

For this survey, the coefficient of concordance is 0.60 .

Since the coefficient of concordance takes values from 0 to 1 , we can conclude that in our example there is a moderate degree of coherence between experts, that is, 1 or 2 experts have found the opposite to other opinions regarding the quality of the course. It may be explained by the fact, when the students took the final achievement exam, some of them were not very successful, so it might their negative feelings about the course due to their lack of conscientiousness.

Let us check the coefficient of concordance on the statistical significance, for which we calculate the Pearson Fitting Criterion (Chernoff and Lehmann 1954). The estimated value of the Pearson Fitting Criterion is 194.65. We found for our data the table value of the Pearson Fitting Criterion. With a probability of 0.95 , it equals 30.14 . The actual value of the criterion exceeds the table and therefore it can be concluded that the calculated coefficient of concordance is statistically significant, that is, the coefficient of concordance adequately reflects the consistency of experts in the survey.

Table 5 below shows a cross-tabulation between the students' level of initial knowledge at the beginning of the course and the level of knowledge after the course. 
Table 5 Level of knowledge comparison at the beginning and at the end of the course

\begin{tabular}{|l|c|c|c|c|c|}
\hline $\begin{array}{l}\text { Ranging from 1 } \\
\text { ("Very Low") to 5 } \\
\text { ("Excellent") }\end{array}$ & \multicolumn{2}{|c|}{$\begin{array}{l}\text { Level of initial } \\
\text { knowledge, (number/\%) }\end{array}$} & $\begin{array}{c}\text { Level of knowledge } \\
\text { after the course, } \\
\text { (number/\%) }\end{array}$ & $\begin{array}{c}\text { Difference between } \\
\text { the initial level and } \\
\text { after completing the } \\
\text { course, \% }\end{array}$ \\
\cline { 2 - 5 } & $\mathrm{N}$ & $\begin{array}{c}\% \text { of } \\
\text { students }\end{array}$ & $\mathrm{N}$ & $\begin{array}{c}\% \text { of } \\
\text { students }\end{array}$ & \\
\hline 1 & & & & & \\
\hline 2 & 3 & 17,64 & & & 17,64 \\
\hline 3 & 8 & 47,06 & 1 & 5,88 & 41,18 \\
\hline 4 & 6 & 35,3 & 7 & 41,18 & 5,88 \\
\hline 5 & & & 9 & 52,94 & 52,94 \\
\hline
\end{tabular}

\section{DISCUSSION AND CONCLUSION}

This study sought to examine student perception of the ESP course for cynological translators to highlight structural components to improve the designing the course. First, based on the concepts of creating the ESP course and the students' perceptions of the structural components and organization of the course whether these constituents will have a positive influence on the achievements after completing the course, we provided some further evidence that the combined well-structured course together with practical experience has improved student achievement after completing the course. This study contributes to the research and literature on the main concepts in designing an ESP course, defining the needs gap, the important parts of the ESP course and the approaches to teaching them, such as vocabulary, speaking, listening, reading, writing. Assessment and feedback is also an important constituent in the teaching process, what completed the investigated object - the course. To our knowledge, it is the first study that demonstrates the process of creating the course for training the cynological translators for working as assistants of show judges.

These findings underscore the importance of examining student reactions to creating courses for specific purposes and identifying any potential pitfalls in course designing. Teachers of any other ESP course can use this type of information to identify the areas where implementation of the course components and structure may need to be improved (e.g., lexis, speaking, practical traineeship, etc.).

Furthermore, we made an assumption that the well-designed course may be successful due to correctly defined needs, components what to teach, due process assessment and practical traineeships. The results proved that the absolute achievement of students has risen from $82,36 \%$ to $100 \%$ and the qualitative achievement has increased by $58,82 \%$, which indicates that the course was successful. Moreover, the rank correlation method demonstrated that the total value of the course together with other related components, such as level of knowledge after the course, the practical value of the course, were confirmed by the high values of this indicator and in relation to the values for other factors. The generalized degree of consistency of opinion on all factors proved the concordance with a moderate degree of coherence between experts. However, the results revealed that 1 or 2 experts have found the opposite to other opinions regarding the quality of the course. This inconsistency might be explained by the different attitude to the education process, as some of the students were not very diligent during the study and successful at the exam. 
Finally, we sought for the further improvements of the course. However, our findings indicate that there is still a need to improve the components of the course, such as vocabulary, listening, writing, reading, speaking with additional content.

Some limitations might be related to collecting our data and interpreting our results. The first limitation might be a small number of the respondents, which can influence the validity of the study results. Although the sample size was deemed acceptable, a larger sample would have allowed us to run more powerful analyses. But this course started two years ago, and there were not many students yet. Another potential shortcoming in the study is the fact that not all structural components of the ESP course were used. For example, we did not provide much practice in writing - this was not professionally demanded.

Despite these limitations, this article illustrates how students' responses to surveys about their perceptions of ESP course can be used to improve the further designing the courses. The article also illustrates the practical ideas about what should be strengthened and paid more attention to in the vocabulary content and in developing the skills.

Overall, the results suggest that to improve the ESP course designing, teachers would need to address individual students' concerns about the content, needs, process, practical training, closely related to the authentic situations, to understand what should be highlighted in the similar courses.

\section{REFERENCES}

Alavi, Sayyed Mohammad, and Reza Dashtestani. "A cross-disciplinary analysis of higher education students' perspectives on the use of e-books for learning academic English." The Asian ESP Journal Volume 1 Issue (2014): 3.

Andrianova, Svetlana, and Anna Makarova. "Terminological dictionaries in ESP training of engineer physicists." Procedia-Social and Behavioral Sciences 236 (2016): 230-234.

Anthony, Laurence. "Defining English for specific purposes and the role of the ESP practitioner." Center for language research 1997 Annual review (1997): 115-120.

Anthony, Laurence. "The teacher as student in ESP course design." The Proceedings of 2007 International Symposium on ESP \& Its Applications in Nursing and Medical English Education. 2007.

Basturkmen, Helen. Developing courses in English for specific purposes. Springer, 2010.

Berwick, Richard, and R. K. Johnson. Needs assessment in language programming: From theory to practice. 1989.

Bracaj, Morena. "Teaching English for specific purposes and teacher training." European Scientific Journal, ESJ 10.2 (2014).

Brindley, Geoffrey. "The role of needs analysis in adult ESL programme design." The second language curriculum (1989): 63-78.

Brooks, Mikio. "The role of vocabulary in English for Specific Purposes (ESP) teaching and learning: Considerations for Asia University." CELE Journal 22 (2014): 157-175.

Cerón, Janese Alane. "A project in English for specific purposes: English for Hispanic workers at a bulk mailing company." (1997).

Chamberlain, Dick, and Robert Jackson Baumgardner. ESP in the Classroom: Practice and Evaluation. Modern English Publications, 1988.

Chernoff, Herman, and Erich L. Lehmann. "The use of maximum likelihood estimates in $\chi^{2}$ tests for goodness of fit." The Annals of mathematical statistics 25.3 (1954): 579-586. 
Coffey, Bernard. "ESP-English for specific purposes." Language teaching 17.1 (1984): 2-16.

Damião, Silvia Matravolgyi. "Course design, action research and the use of computers: challanges in an ESP course." Revista Brasileira de Linguística Aplicada 11.4 (2011): 913-934.

Douglas, Dan. "Language for Specific Purposes assessment criteria: where do they come from?." Language Testing 18.2 (2001): 171-185.

Douglas, Dan. "Three problems in testing language for specific purposes: Authenticity, specificity and inseparability." Experimenting with uncertainty: essays in Honour of Alan Davies. Cambridge University Press, 2001.

Dudley-Evans, Tony, Maggie Jo St John, and Maggie Jo Saint John. Developments in English for specific purposes: A multi-disciplinary approach. Cambridge university press, 1998.

Farrell, Thomas SC. "Lesson planning." Methodology in language teaching: An anthology of current practice (2002): 30-39.

Frydenberg, Gro. "Designing an ESP reading skills course." ELT journal 36.3 (1982): 156-163.

Giménez, Julio César. "Process assessment in ESP: Input, throughput and output." English for Specific Purposes 15.3 (1996): 233-241.

Huckin, Thomas N. "Achieving professional communicative relevance in a generalized ESP classroom." Chamberlain and Baumgardner (1988): 62-70.

Huhta, Marjatta, et al. Needs analysis for language course design: A holistic approach to ESP. Cambridge University Press, 2013.

Hutchinson, Tom, and Alan Waters. "How communicative is ESP?." ELT journal 38.2 (1984): 108-113.

Hutchinson, Tom, and Alan Waters. English for specific purposes. Cambridge University Press, 1987.

Javid, Choudhary Zahid. "English for specific purposes: role of learners, teachers and teaching methodologies." European Scientific Journal, ESJ 11.20 (2015).

Kaur, Sarjit. "ESP course design: Matching learner needs to aims." English for Specific Purposes 6.1 (2007): 25-37.

Kavaliauskienë, Galina, and Violeta Janulevièienë. "Using the lexical approach for the Acquisition of ESP vocabulary." The Internet TESL Journal 7.3 (2001): 1-6.

Khan, Agha Masood Ahmad, Abdul Ghafoor Awan, and Muhammad Imran Afzal. "Need to Design an ESP Course for Medical Representatives in Pakistan.

Klimova, Blanka. "Developing ESP study materials for students at a non-philological faculty." Procedia-Social and Behavioral Sciences 197 (2015): 104-107.

Knoch, Ute, et al. "Transitioning from university to the workplace: Stakeholder perceptions of academic and professional writing demands." IELTS Research Reports Online Series (2016): 37.

Lin, Jun, Aiguo Wang, and Changjie Zhang. "Integrating Curriculum Design Theory into ESP Course Construction: Aviation English for Aircraft Engineering." Open Journal of Modern Linguistics 4.02 (2014): 219.

Lowe, I. "Principles of ESP course design." (2009).

Milić, Mira. "Principles of Compiling an English-Serbian Dictionary of Sports Terms in the Modern Anglo-globalized World." ESP Today: Journal of English for Specific Purposes at Tertiary Level 3.2 (2015): 180-195. 
Nurpahmi, Sitti. "ESP Course Design: An Integrated Approach." Lentera Pendidikan: Jurnal Ilmu Tarbiyah Dan Keguruan 19.2 (2017): 172-181.

Petrova, Iryna. "Needs analysis as a starting point for designing a syllabus for English for specific purposes courses." Unpublished dissertation, University of Tarku, Department of English Language and Literature (2008).

Pranckevičiūte, Vilma, and Zita Zajankauskaitè. "Adjusting an ESP course to students' needs in tertiary education: A case study." Studies about languages 21 (2012): 115-123.

Robinson, Pauline C. ESP today: A practitioner's guide. Hemel Hempstead: Prentice Hall, 1991.

Salazar, Elvia Ureña. "Designing and Implementing an ESP Course: Revisiting an Experience." Pensamiento Actual 17.28 (2017): 197-207.

Sanz, Ana Gimeno, and Antonio Martínez Sáez. "The design and integration of ESP content in an upper-intermediate online course." Revista de Lenguas para Fines Específicos 22.1 (2016): 31-53.

Schleppegrell, Mary, and Brenda Bowman. "ESP: Teaching English for Specific Purposes." (1986).

Schleppegrell, Mary. "Economic input: An ESP program." The ESP Journal 4.2 (1985): 111-119.

Shepard, Lorrie A. "Measuring Achievement: What Does It Mean To Test for Robust Understanding? William H. Angoff Memorial Lecture Series." (1997).

Stefanescu, Maria. " Designing an ESP Course for Theology Students." Studia Universitatis Babes-Bolyai, Philologia 58.2 (2013).

Todea, L., and R. Demarcsek. "Needs analysis for language course design. A case study for engineering and business students." IOP Conference Series: Materials Science and Engineering. Vol. 200. No. 1. IOP Publishing, 2017.

$\mathrm{Wu}$, Jiangwen, and Binbin Wang. "The role of vocabulary in ESP teaching and learning." ELT journal 27 (2004): 223-224.

Xhaferi, Brikena. "Teaching and learning ESP vocabulary." Revista de Lenguas para Fines Específicos 16 (2015): 229-255.

\section{APPENDIX A}

Supplementary data is available online at this link:

https://drive.google.com/open?id=1XSffNpYwF7onwOa7tlF5awOdGM5iL_MO 